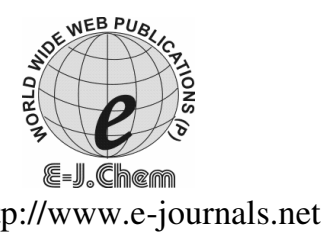

ISSN: 0973-4945; CODEN ECJHAO

E-Journal of Chemistry 2010, 7(2), 449-456

\title{
Synthesis and Antimicrobial Activity of Quinazolinone Conjugated Peptides
}

\author{
G. P. SURESHA, K. C. PRAKASHA, \\ WETHROE KAPFO and D. CHANNE GOWDA* \\ Department of Chemistry, \\ Manasagangotri, University of Mysore, Mysore-570006, India. \\ dchannegowda@yahoo.co.in
}

Received 10 September 2009; Accepted 5 November 2009

\begin{abstract}
Antimicrobial compounds were synthesized by coupling 4-(4oxo-3,4-dihydroquinazolin-2-yl) butanoic acid with VP, GVP, VGVP and GVGVP peptides. Antimicrobial activities of the synthesized compounds were performed against various bacterial strains by disc diffusion method. The structure activity relationship was evaluated with respect to hydrophobicity, polarity, chain length of peptides and alkyl chain length of quinazolinone. Correlations of analogs with respect to their antimicrobial activity in comparison with conventional drugs and probable mechanism for the activity were discussed.
\end{abstract}

Keywords: Antimicrobial drugs, Quinazolinone conjugated peptides, Hydrophobicity, Polarity, Chain length.

\section{Introduction}

In recent past pharmacological applications witnessed an unprecedented rate of the spread of microbes that are resistant to conventional antimicrobials worldwide. This poses a threat and the rapid emergence of resistant stains involve both gram-positive and gram-negative ${ }^{1}$. Efforts are currently underway to find new antimicrobials which act in a different mechanism of action against microbes and can potentially evade resistance provided by microbes. In order to achieve this in an efficient manner, it is important to understand the mechanism of action of these agents and the reason for their selectivity against microbes ${ }^{2}$. 
Antimicrobial peptides are found in most living organisms and have been most interesting compounds due to their structure and unique mode of action different from the most conventional antimicrobials ${ }^{3}$. These peptides exhibit activity against a broad spectrum of microbes but showed fairly low activity. Also several classes of antimicrobial peptides have been studied and their mechanisms of action against several microbes not yet clear and its elucidation would form a sound basis for the further development of new pharmaceutical compounds ${ }^{4}$.

Another class of compounds of interest in this scenario is quinazolinone alkaloids and its analogues ${ }^{5}$. These compounds extracted from natural sources were used as antimicrobials from long time. But recently mimicking of theses compounds with synthetic routes were found valuable route to find a new candidate as antimicrobials ${ }^{6}$.

In our earlier work, we have developed novel quinazolinone conjugated peptides by coupling peptides with 4-(4-oxo-3, 4-dihydroquinazolin-2-yl)propanoic acid (Precursor 1) ${ }^{7}$. The resulted compounds showed enhanced activity against both gram positive and gram negative bacterial strains compared to conventional antimicrobial viz., Streptomycin and tetracyclin. Further the activity depends on structural entities of the compounds; we were interested to extend the work by introducing the analogue of precursor $\mathbf{1}$ with mentioned peptides. The analogues were different from earlier compounds by elongating the alkyl chain as given in structures $\mathbf{2 a - 9 a}$. These new chemical entities were synthesized by coupling mentioned peptides with 4-(4-oxo-3,4-dihydroquinazolin-2-yl) butanoic acid (1a) and evaluated for their antimicrobial activities against various bacterial strains.

\section{Experimental}

All chemicals and reagents were obtained from Aldrich (USA), Spectrochem Pvt. Ltd (India) and Rankem Pvt. Ltd. (India) and were used without further purification. The amino acids used were $L$ - series unless mentioned. The ${ }^{1} \mathrm{H}$ NMR, mass and HPLC spectra were recorded on $300 \mathrm{MHz}$ Bruker FT-NMR Spectrometer, LCMSD-Trap-XCT instrument and Agilent-1100 HPLC respectively. The bacterial strains used were obtained from department of Studies in Biotechnology, University of Mysore, India, namely, Bacillus substilis, Escherichia coli, Pseudomonas fluorescens, Xanthomonas campestris pvs and Xanthomonas oryzae.

\section{Synthesis}

The 4-(4-oxo-3,4-dihydroquinazolin-2-yl)butanoic acid (1a) was synthesized as previously reported using anthranilide and pentanedioic acid anhydride ${ }^{7,8}$. The peptides were synthesized by stepwise solution phase method using Boc chemistry. The Boc group was used for temporary $N^{\alpha}$-protection and its removal was achieved with TFA. The resulting peptides were coupled with 1a as shown in the Scheme 1. The carboxyl group was protected by benzyl ester and its removal was effected by hydrogenolysis using $\mathrm{HCO}_{2} \mathrm{NH}_{4}$ as hydrogen donor and $10 \%$ Pd-C on carbon as catalyst, described by our earlier method ${ }^{7}$. The series of compounds $2 \mathbf{a}, \mathbf{4 a}, \mathbf{6 a}, \mathbf{8 a}$ possess precursor 1a coupled with benzyl esters of VP, GVP, VGVP and GVGVP peptides and compounds 3a, 5a, 7a, 9a were their hydrolyzed products respectively. 
General procedure for the synthesis of 4-(4-oxo-3,4-dihydroquinazolin-2$y$ l)butanoic acid conjugated peptides $(2 \boldsymbol{a}-\mathbf{9 a})$<smiles>CC(C)C(N)C(=O)N1CCCC1C(=O)OCc1ccccc1</smiles><smiles>CC(C)C(NC(=O)CCCc1nc2ccccc2c(=O)[nH]1)C(=O)N1CCCC1C(=O)OCc1ccccc1</smiles>

2a<smiles>CC(C)C(NC(=O)CCCc1nc2ccccc2c(=O)[nH]1)C(=O)N1CCCC1C(=O)O</smiles>

$3 \mathbf{a}$

(i) $\mathrm{EDCl} / \mathrm{HOBt}$ and DIEA,(ii) $\mathrm{HCO}_{2} \mathrm{NH}_{4} / 10 \%$ Pd-C

Scheme 1. Synthesis of heterocyclic conjugated peptides.

The coupling of 4-(4-oxo-3,4-dihydroquinazolin-2-yl)butanoic acid with benzyl esters of peptides

To the stirred solution of 4-(4-oxo-3,4-dihydroquinazolin-2-yl)butanoic acid $(0.2 \mathrm{~g}, 0.86 \mathrm{mmol})$ in DMF $(5.0 \mathrm{~mL})$ cooled to ${ }^{0} \mathrm{C}$ with crushed ice, added TFA.VP-OBzl $(0.36 \mathrm{~g}, 0.86 \mathrm{mmol})$, DIEA (0.61 mL, $3.44 \mathrm{mmol}), \mathrm{HOBt}(0.17 \mathrm{~g}, 1.29 \mathrm{mmol})$, EDCI $(0.33 \mathrm{~g}, 1.72 \mathrm{mmol})$ and THF $(5 \mathrm{~mL})$. The reaction mixture was stirred over night while slowly warming to room temperature. The reaction was quenched with $\mathrm{H}_{2} \mathrm{O}(2 \mathrm{~mL})$ and the solvent was condensed. The residue was dissolved in EtOAc $(30 \mathrm{~mL})$ and the organic layer was washed with $1 \mathrm{~N} \mathrm{HCl}(1 \times 20 \mathrm{~mL})$, saturated $\mathrm{NaHCO}_{3}$ solution $(1 \times 20 \mathrm{~mL})$ and brine $(1 \times 20 \mathrm{~mL})$. Then the organic layer was dried over $\mathrm{MgSO}_{4}$ and concentrated at high vacuum. Chromatography (10\% EtOAc-Hexane) over silica gel (100-200) provided compound 2a as white hygroscopic foam (Yield: 87\%).

\section{Hydrogenolysis of benzyl ester of heterocyclic conjugated peptides}

To a stirred solution of compound $2 \mathbf{a}(0.15 \mathrm{~g})$ and $10 \% \mathrm{Pd} / \mathrm{C}(10 \% \mathrm{w} / \mathrm{w})$ in methanol $(2.5 \mathrm{~mL})$, ammonium formate ( 2 equiv) was added. The resulting reaction mixture was stirred at room temperature. After the completion of hydrogenolysis (monitored by TLC), the mixture was filtered through celite and washed with methanol. The combined washings and filtrate 
were evaporated. The residue was taken up in chloroform and washed with 50\% saturated $\mathrm{NaC} 1$ solution to remove ammonium formate. The solvent was removed under reduced pressure and triturated with ether to obtain the hydrolyzed compound 3a (Yield: 90\%).

\section{Analytical data of synthesized compounds}

The spectral data $\left(\mathrm{H}^{1} \mathrm{NMR}\right.$ and mass spectra) confirmed the structures of the synthesized compounds. The analytical data of the compounds are given below.

Compound 2a: Yield: 87\%., ${ }^{1} \mathrm{H}$ NMR (DMSO-D $): \delta 12.16(\mathrm{~s}, 1 \mathrm{H}), 8.11-8.07(\mathrm{t}, 2 \mathrm{H}$, $\mathrm{J}=9.0 \mathrm{~Hz}), 7.77-7.75(\mathrm{~d}, 1 \mathrm{H}, \mathrm{J}=8.2 \mathrm{~Hz}), 7.60-7.58(\mathrm{~d}, 1 \mathrm{H}, \mathrm{J}=8.1 \mathrm{~Hz}), 7.48-7.36(\mathrm{t}, 1 \mathrm{H}$, $\mathrm{J}=7.8 \mathrm{~Hz}), 7.34(\mathrm{~s}, 5 \mathrm{H}), 5.11(\mathrm{~s}, 2 \mathrm{H}), 4.40-4.38(\mathrm{~m}, 1 \mathrm{H}), 4.37-4.36(\mathrm{~m}, 1 \mathrm{H}), 3.74-3.72(\mathrm{~m}$, $1 \mathrm{H}), 3.71(\mathrm{~m}, 1 \mathrm{H}), 2.58-2.57(\mathrm{~m}, 2 \mathrm{H}), 2.22-2.18(\mathrm{~m}, 3 \mathrm{H}), 1.95-1.93(\mathrm{~m}, 5 \mathrm{H}), 1.91-1.90(\mathrm{~m}$, $1 \mathrm{H}), 0.87-0.84(\mathrm{~d}, 6 \mathrm{H}, \mathrm{J}=11.8)$. MS $m / z: 519.2\left(\mathrm{M}^{+}\right)$.

Compound 3a: Yield: 90\%., ${ }^{1} \mathrm{H}$ NMR (DMSO-D $): \delta 12.18$ ( s, 1H), 8.11-8.07 (t, 2H, J=9.0Hz), 7.77-7.75 (d, $1 \mathrm{H}, \mathrm{J}=8.2 \mathrm{~Hz}), 7.60-7.58(\mathrm{~d}, 1 \mathrm{H}, \mathrm{J}=8.1 \mathrm{~Hz}), 7.48-7.36(\mathrm{t}, 1 \mathrm{H}, \mathrm{J}=7.8 \mathrm{~Hz}), 4.40-4.38$ (m, $1 \mathrm{H}), 4.37-4.35(\mathrm{~m}, 1 \mathrm{H}), 3.75-3.72(\mathrm{~m}, 1 \mathrm{H}), 3.71-3.70(\mathrm{~m}, 1 \mathrm{H}), 2.58-2.57(\mathrm{~m}, 2 \mathrm{H}), 2.20-2.18(\mathrm{~m}, 3 \mathrm{H})$, 1.95-1.94 (m, 5H), 1.91-1.90 (m, 1H), 0.86-0.84 (d, 6H, J=11.8).MS m/z: $429.3\left(\mathrm{M}^{+}\right)$.

Compound 4a: Yield: 86\%., ${ }^{1} \mathrm{H}$ NMR (DMSO-D $): \delta 12.16(\mathrm{~s}, 1 \mathrm{H}), 8.08-8.06(\mathrm{~d}, 3 \mathrm{H}$, $\mathrm{J}=8.0 \mathrm{~Hz}), 7.77-7.75(\mathrm{~d}, 1 \mathrm{H}, \mathrm{J}=8.2 \mathrm{~Hz}), 7.62-7.60(\mathrm{~d}, 1 \mathrm{H}, \mathrm{J}=8 \mathrm{~Hz}), 7.47-7.46(\mathrm{t}, 1 \mathrm{H}$, $\mathrm{J}=7.4 \mathrm{~Hz}), 7.34(\mathrm{~s}, 5 \mathrm{H}), 5.11(\mathrm{~s}, 2 \mathrm{H}), 4.38-4.32(\mathrm{~m}, 2 \mathrm{H}), 3.73(\mathrm{~m}, 1 \mathrm{H}), 3.72(\mathrm{~m}, 2 \mathrm{H}), 3.71(\mathrm{~m}$, $1 \mathrm{H}), 2.61-2.50(\mathrm{~m}, 2 \mathrm{H}), 2.21-2.19(\mathrm{~m}, 3 \mathrm{H}), 1.95-1.93(\mathrm{~m}, 5 \mathrm{H}), 1.91-1.89(\mathrm{~m}, 1 \mathrm{H}), 0.87-0.82$ (m, 6H). MS $m / z: 576.2\left(\mathrm{M}^{+}\right)$.

Compound 5a: Yield: 86\%., ${ }^{1} \mathrm{H}$ NMR(DMSO-D $): \delta 12.17(\mathrm{~s}, 1 \mathrm{H}), 8.08-8.06(\mathrm{~d}, 3 \mathrm{H}$, $\mathrm{J}=8.0 \mathrm{~Hz}), 7.77-7.75(\mathrm{~d}, 1 \mathrm{H}, \mathrm{J}=8.2 \mathrm{~Hz}), 7.62-7.60(\mathrm{~d}, 1 \mathrm{H}, \mathrm{J}=8 \mathrm{~Hz}), 7.47-7.46(\mathrm{t}, 1 \mathrm{H}, \mathrm{J}=7.4 \mathrm{~Hz})$, 4.38-4.34 (m, 2H), 3.74(m, 1H), $3.72(\mathrm{~m}, 2 \mathrm{H}), 3.70(\mathrm{~m}, 1 \mathrm{H}), 2.62-2.50(\mathrm{~m}, 2 \mathrm{H}), 2.20-2.19(\mathrm{~m}$, $3 \mathrm{H}), 1.96-1.92(\mathrm{~m}, 5 \mathrm{H}), 1.91-1.89(\mathrm{~m}, 1 \mathrm{H}), 0.86-0.82(\mathrm{~m}, 6 \mathrm{H}) . \mathrm{MS} m / z: 484.4\left(\mathrm{M}^{-}\right)$.

Compound 6a: Yield: $85 \% .,{ }^{1} \mathrm{H}$ NMR (DMSO-D ${ }_{6}$ ): $\delta 12.17$ (s, 1H), $8.23(\mathrm{~s}, 1 \mathrm{H}), 8.09-$ $8.07(\mathrm{~d}, 1 \mathrm{H}, \mathrm{J}=8.4 \mathrm{~Hz}), 7.93-7.91(\mathrm{~d}, 2 \mathrm{H}, \mathrm{J}=8.4 \mathrm{~Hz}), 7.90-7.77(\mathrm{t}, 1 \mathrm{H}, \mathrm{J}=7.6 \mathrm{~Hz}), 7.75-$ $7.73(\mathrm{~d}, 1 \mathrm{H}, \mathrm{J}=8.4 \mathrm{~Hz}), 7.48-7.46(\mathrm{t}, 1 \mathrm{H}, \mathrm{J}=7.6 \mathrm{~Hz}), 7.35(\mathrm{~s}, 5 \mathrm{H}), 5.11(\mathrm{~s}, 2 \mathrm{H}), 4.36(\mathrm{~m}, 2 \mathrm{H})$, 4.33(m, 1H), 3.75-3.73 (m, 3H), 3.72 (m, 1H), 2.85-2.84 (m, 2H), 2.25-2.24 (m, 3H), 1.97$1.95(\mathrm{~m}, 6 \mathrm{H}), 1.92-1.90(\mathrm{~m}, 1 \mathrm{H}), 0.86-0.81(\mathrm{~m}, 12 \mathrm{H}) . \mathrm{MS} m / z: 674.8\left(\mathrm{M}^{+}\right)$.

Compound 7a: Yield: 86\%., ${ }^{1} \mathrm{H}$ NMR (DMSO-D $): \delta 12.18(\mathrm{~s}, 1 \mathrm{H}), 8.24(\mathrm{~s}, 1 \mathrm{H})$, 8.09-8.07 (d, $1 \mathrm{H}, \mathrm{J}=8.4 \mathrm{~Hz}), 7.93-7.91(\mathrm{~d}, 2 \mathrm{H}, \mathrm{J}=8.4 \mathrm{~Hz}), 7.90-7.77(\mathrm{t}, 1 \mathrm{H}, \mathrm{J}=7.6 \mathrm{~Hz})$, 7.75-7.73(d, $1 \mathrm{H}, \mathrm{J}=8.4 \mathrm{~Hz}), 7.48-7.46(\mathrm{t}, 1 \mathrm{H}, \mathrm{J}=7.6 \mathrm{~Hz}), 4.38(\mathrm{~m}, 2 \mathrm{H}), 4.33(\mathrm{~m}, 1 \mathrm{H}), 3.74-$ $3.73(\mathrm{~m}, 3 \mathrm{H}), 3.72(\mathrm{~m}, 1 \mathrm{H}), 2.85-2.83(\mathrm{~m}, 2 \mathrm{H}), 2.26-2.24(\mathrm{~m}, 3 \mathrm{H}), 1.97-1.94(\mathrm{~m}, 6 \mathrm{H}), 1.93-$ $1.90(\mathrm{~m}, 1 \mathrm{H}), 0.86-0.80(\mathrm{~m}, 12 \mathrm{H})$. MS m/z: $585.2\left(\mathrm{M}^{+}\right)$.

Compound 8a: Yield: 83\%., ${ }^{1} \mathrm{H}$ NMR (DMSO-D $): ~ \delta 12.19$ (s, 1H), 8.24-8.22 (m, 1H), 8.11$8.09(\mathrm{~m}, 2 \mathrm{H}), 7.97-7.95(\mathrm{~d}, 1 \mathrm{H}, \mathrm{J}=8.4 \mathrm{~Hz}), 7.89-7.86(\mathrm{~m}, 2 \mathrm{H}), 7.86-7.84(\mathrm{~d}, 1 \mathrm{H}, \mathrm{J}=8.1 \mathrm{~Hz}), 7.70-7.53$ $(\mathrm{t}, 1 \mathrm{H}, \mathrm{J}=7.6 \mathrm{~Hz}), 7.34(\mathrm{~s}, 5 \mathrm{H}), 5.10(\mathrm{~s}, 2 \mathrm{H}), 4.35-4.32(\mathrm{~m}, 2 \mathrm{H}), 4.14(\mathrm{~m}, 1 \mathrm{H}), 3.73-3.55(\mathrm{~m}, 6 \mathrm{H})$, 2.71-2.65 (m, 2H), 2.24-2.21 (m, 3H), 1.98-1.87 (m, 7H), 0.84-0.80 (m, 12H). MS m/z: $731.8\left(\mathrm{M}^{+}\right)$.

Compound 9a: Yield: 88\%. ${ }^{1} \mathrm{H}$ NMR (DMSO-D $): \delta \delta 12.20(\mathrm{~s}, 1 \mathrm{H}), 8.25-8.22(\mathrm{~m}, 1 \mathrm{H})$, 8.11-8.08 (m, 2H ), 7.97-7.95 (d, 1H, J=8.4Hz), 7.90-7.86 (m, 2H), 7.86-7.84 (d, 1H, J= 8.1Hz), 7.70-7.53 (t,1H, J= 7.6Hz), 4.35-4.33 (m, 2H), 4.14-4.20 (m, 1H), 3.73-3.59 (m, 6H), 2.70-2.65 $(\mathrm{m}, 2 \mathrm{H}), 2.24-2.22(\mathrm{~m}, 3 \mathrm{H}), 1.98-1.87(\mathrm{~m}, 7 \mathrm{H}), 0.85-0.80(\mathrm{~m}, 12 \mathrm{H}) . \mathrm{MS} m / z: 642.5\left(\mathrm{M}^{+}\right)$ 


\section{Antibacterial assay}

In vitro antibacterial assays were performed against Bacillus substilis, Escherichia coli, Pseudomonas fluorescens, Xanthomonas campestris pvs and Xanthomonas oryzae by using the disc diffusion method ${ }^{9}$. The bacterial strains were maintained on LB agar medium at 28 ${ }^{\circ} \mathrm{C}$. The bacteria were grown in LB broth, centrifuged at $10,000 \mathrm{rpm}$ for $5 \mathrm{~min}$; pellet was dissolved in double distilled water and used to inoculate the plates. The paper discs containing streptomycin and tetracyclin were used as positive control and DMSO as negative control. Each disc contained $10 \mu \mathrm{g}$ of standard drugs and $10 \mu \mathrm{g}$ synthesized compounds. Plates were first kept at $4{ }^{\circ} \mathrm{C}$ for $2 \mathrm{~h}$ to allow the diffusion of chemicals and then incubated at $28{ }^{\circ} \mathrm{C}$. All the compounds were tested in triplicate and inhibition zones were measured in $\mathrm{mm}$ after $24 \mathrm{~h}$ of incubation.

Table 1. Heterocyclic conjugated peptides with their analytical data.<smiles>O=C(O)CCc1nc2ccccc2c(=O)[nH]1</smiles><smiles>O=C(O)CCCc1nc2ccccc2c(=O)[nH]1</smiles><smiles>[R]NC(=O)CCCc1nc2ccccc2c(=O)[nH]1</smiles>

\begin{tabular}{clcccc}
\hline $\begin{array}{c}\text { Compound } \\
\text { No. }\end{array}$ & \multicolumn{1}{c}{$\mathrm{R}^{\mathrm{a}}$} & $\begin{array}{c}\text { Theoretical } \\
\text { Mol. Wt. }\end{array}$ & $\begin{array}{c}\text { Actual MS } \\
\text { Values }\left(\mathrm{M}^{+}\right)\end{array}$ & Formula & $\begin{array}{c}\text { HPLC } \\
\text { RT }\end{array}$ \\
\hline 2a & VP-OBzl & 518.25 & 519.2 & $\mathrm{C}_{29} \mathrm{H}_{34} \mathrm{~N}_{4} \mathrm{O}_{5}$ & 9.070 \\
3a & VP-OH & 428.21 & 429.3 & $\mathrm{C}_{22} \mathrm{H}_{28} \mathrm{~N}_{4} \mathrm{O}_{5}$ & 5.397 \\
4a & GVP-OBzl & 575.27 & 576.2 & $\mathrm{C}_{31} \mathrm{H}_{37} \mathrm{~N}_{5} \mathrm{O}_{6}$ & 9.086 \\
$\mathbf{5 a}$ & GVP-OH & 485.23 & $484.4\left(\mathrm{M}^{-}\right)$ & $\mathrm{C}_{24} \mathrm{H}_{31} \mathrm{~N}_{5} \mathrm{O}_{6}$ & 5.659 \\
6a & VGVP-OBzl & 674.34 & 674.8 & $\mathrm{C}_{36} \mathrm{H}_{46} \mathrm{~N}_{6} \mathrm{O}_{7}$ & 9.125 \\
$\mathbf{7 a}$ & VGVP-OH & 584.30 & 585.2 & $\mathrm{C}_{29} \mathrm{H}_{40} \mathrm{~N}_{6} \mathrm{O}_{7}$ & 7.038 \\
8a & GVGVP-OBzl & 731.36 & 731.8 & $\mathrm{C}_{38} \mathrm{H}_{49} \mathrm{~N}_{7} \mathrm{O}_{8}$ & 9.300 \\
9a & GVGVP-OH & 641.32 & 642.5 & $\mathrm{C}_{31} \mathrm{H}_{43} \mathrm{~N}_{7} \mathrm{O}_{8}$ & 7.072 \\
\hline
\end{tabular}

${ }^{a} G=$ Glycine, $P=$ Proline, $V=$ Valine

\section{Results and Discussion}

The biological activities of the synthesized quinazolinone conjugated peptides were tested against bacterial strains, Bacillus-substilis (gram positive) and Escherichia-coli, Pseudomonas-fluorescens, Xanthomonas-campestris pvs and Xanthomonas-oryzae (gram negative) and are given in Table 2. Each fragment of these compounds i.e 4-(4-oxo-3,4dihydroquinazolin-2-yl)butanoic acid, VP, GVP, VGVP and GVGVP peptides were tested for antibacterial activity and found inactive ${ }^{10}$. Even though the peptides chosen were less hydrophobic and inactive towards mentioned bacterial strains, their conjugation with precursor 1a showed increased antimicrobial activity (Table 2).

From the Table 2, it is observed that the antimicrobial activity increases with increase in length of peptide chain. Both benzylated and debenzylated product of quinazolinone conjugated peptides (2a-9a) showed parallel trends towards the antimicrobial activity with respect to peptide chain length. However, the debenzylated product of these molecules (3a, $\mathbf{5 a}, \mathbf{7 a}, \mathbf{9 a})$ showed enhanced activity than its respective counterparts $(\mathbf{2 a}, \mathbf{4 a}, \mathbf{6 a}, \mathbf{8 a})$. It was observed that the quinazolinone conjugated with VGVP and GVGVP (6a, 7a, 8a, 9a) showed increased activities in comparison with the conventional drugs (Table 2). 
In order to correlate the appropriate structure activity relationship, the hydrophobicity of synthesized molecules was evaluated using RP-HPLC, C18 column surface which has affinity for hydrophobicity ${ }^{11}$, so more retained compound have higher hydrophobic nature. A plot of retention time of compounds against its antimicrobial activity (Figure 1) showed that both benzylated and its hydrolyzed compounds (2a - 9a) having more elongated peptide chain exhibits more hydrophobic nature and showed higher antimicrobial activities compared to the compounds having shorter peptide chain. But hydrolyzed compounds (3a, 5a, 7a, 9a) exhibit less hydrophobic character compared to their counterparts $(\mathbf{2} \mathbf{a}, \mathbf{4 a}, \mathbf{6 a}, \mathbf{8 a})$, still they have shown more antimicrobial activity. This may be due to increase in polarity of these compounds and indicates that increase in the polarity also has an impact on the activity ${ }^{12}$.

Table 2. Inhibitory Zone (diameter) mm of compounds against tested bacterial strains by disc diffusion method.

\begin{tabular}{cccccc}
\hline \multirow{2}{*}{ Compounds } & \multicolumn{5}{c}{ Inhibitory zone (diameter) $\mathrm{mm}^{\mathrm{a}}$} \\
\cline { 2 - 6 } & $\begin{array}{c}\text { Bacillus- } \\
\text { substilis }\end{array}$ & $\begin{array}{c}\text { Escherichia- Pseudomonas- } \\
\text { coli }\end{array}$ & $\begin{array}{c}\text { Xanthomonas- } \\
\text { fluorescens }\end{array}$ & $\begin{array}{c}\text { Xampestris pvs. } \\
\text { camonas- } \\
\text { oryzae }\end{array}$ \\
\hline 1a & 0 & 0 & 0 & 0 & 0 \\
2a & 6 & 7 & 5 & 4 & 6 \\
3a & 8 & 10 & 9 & 7 & 8 \\
4a & 10 & 8 & 9 & 6 & 5 \\
5a & 11 & 10 & 10 & 13 & 11 \\
6a & 18 & 19 & 18 & 20 & 17 \\
$7 \mathrm{a}$ & 20 & 23 & 22 & 23 & 21 \\
8a & 21 & 20 & 24 & 23 & 26 \\
9a & 28 & 24 & 27 & 28 & 30 \\
Streptomycin & 17 & 21 & 23 & - & - \\
Tetracycline & - & - & - & 19 & 18 \\
\hline
\end{tabular}

Streptomycin (10 $\mu \mathrm{g} /$ disc), Tetracycline $(10 \mu \mathrm{g} /$ disc) were used as positive control \& compounds $(10 \mu \mathrm{g} /$ disc $)$

${ }^{a}$ Values are means of three determinations, the ranges of which are less than $5 \%$ of the mean in all cases.

Bacillus subtilis (+)

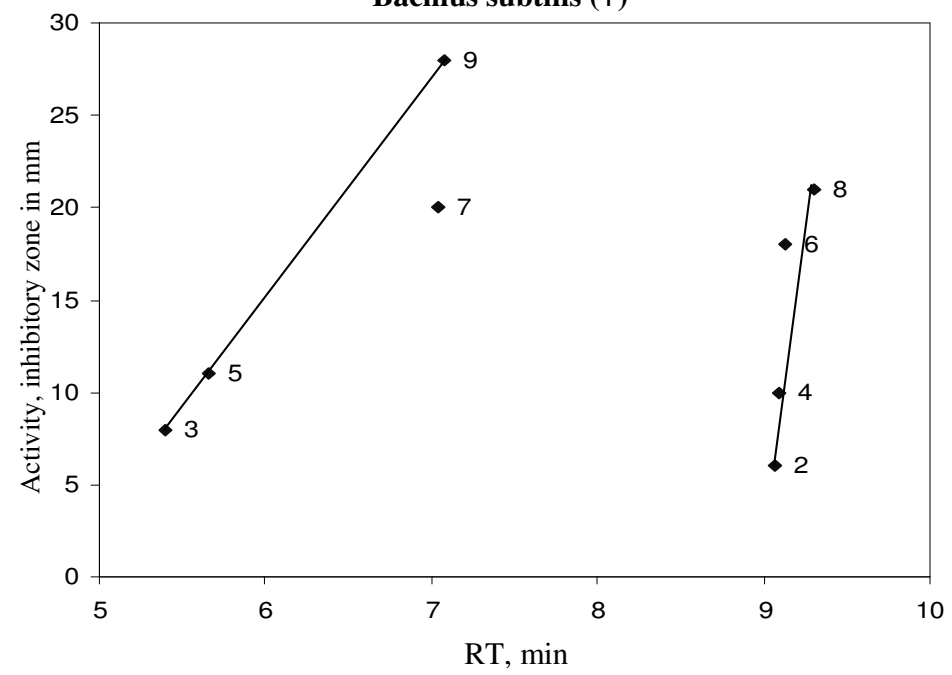

Figure 1. Correlation between RT and antibacterial activity. 
Indeed, 4-(4-oxo-3,4-dihydroquinazolin-2-yl)butanoic acid conjugated peptides (2a-9a) having an additional methylene group in its alkyl chain showed less hydrophobic nature and also showed the slightly lesser antimicrobial activities compare to that of 4-(4-oxo-3,4dihydroquinazolin-2-yl)propanoic acid conjugated peptide (2-9) which has been discussed in our previous study ${ }^{7}$. To evaluate this, a plot of antimicrobial activities of 4-(4-oxo-3,4dihydroquinazolin-2-yl)butanoic acid and 4-(4-oxo-3,4-dihydroquinazolin-2-yl)propanoic acid conjugated peptides against their retention times is presented in Table 2. From the Figure 2, it is evident that the increase in the length of carbon chain in quinazolinone precursors has little / no impact on the activity of the molecules. Both the set of molecules ( 2 - 9 and 2a - 9a) showed similar and steady increase in activity as peptide chain length and hydrophobicity (HPLC-RT) increases.

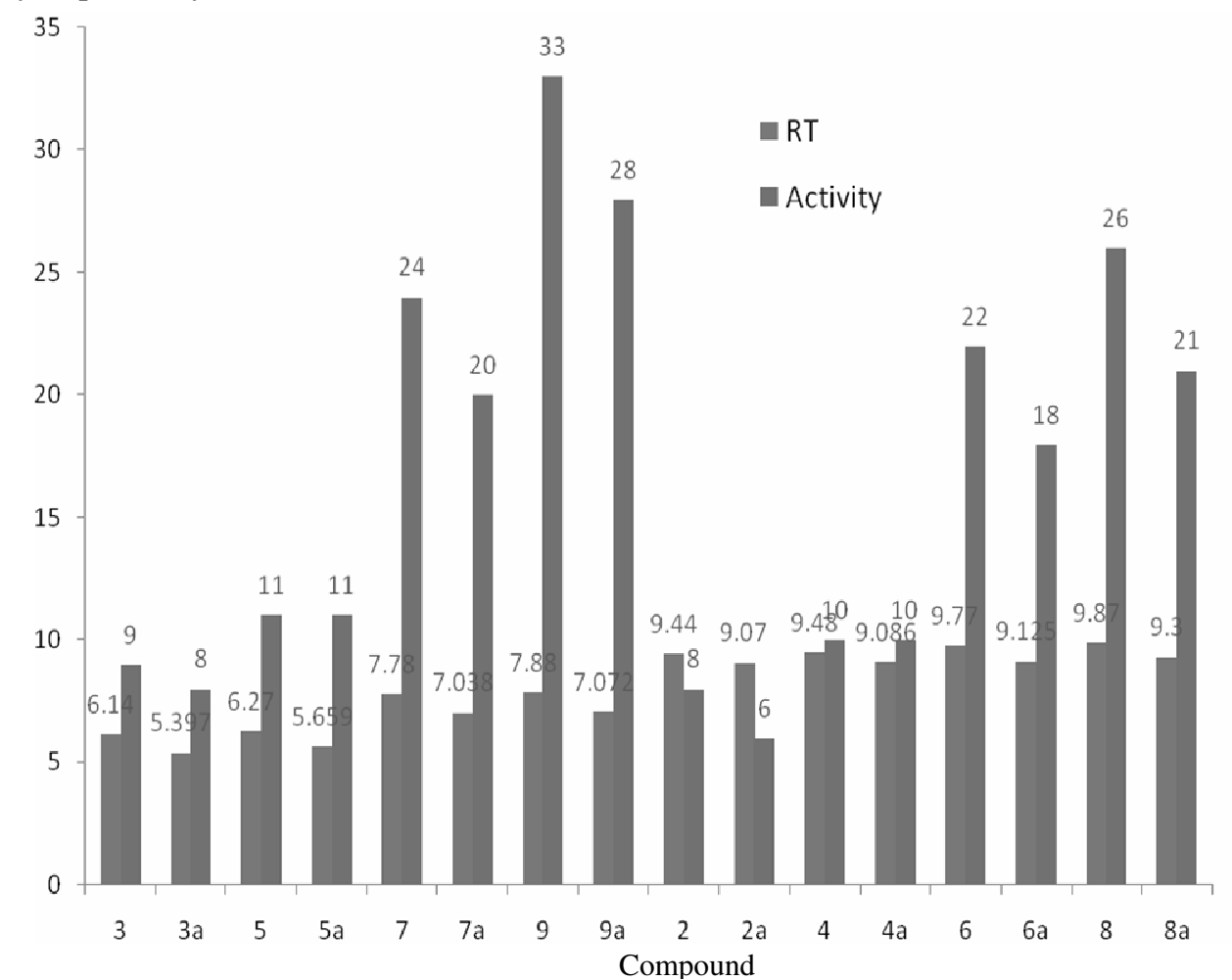

Figure 2. RT \& microbial activity of B. subtilis.

Further it is evident that activity towards gram -ve bacteria is more compared to the gram $+v e$. This may be due to the distance between the charged groups and the heterocyclic ring. Another widely postulated mechanism is that of the "self-promoted uptake" of the peptides across the outer membranes of gram negative bacteria which consists lipopolysaccaride surface ${ }^{13}$. This suggest that the peptides interact with the negatively charged outer membrane and subsequent channel formation in the cytoplasmic membrane via either "barrel-stave" or a" carpet" mechanism resulting in cell death ${ }^{14}$.

\section{Conclusion}

Following our ongoing investigations on development of quinazolinone conjugated peptides as novel antimicrobial agents, in the present study, by enhancing the alkyl chain length in 
the quinazolinone showed similar activities but fairly less compare to quinazolinone of shorter alkyl chain length. Thus, the increase in the length of carbon chain in quinazolinone precursors may have little / no impact on the activity of the molecules. But the length of peptide chain, hydrophobicity and variation in polarity of these molecules play important role in their antimicrobial activities. It was noticed that quinazolinone conjugated VGVP and GVGVP peptides showed increased activity by nearly two fold compared to conventional antimicrobials.

\section{References}

1. Hand W L, Adolesc Med., 2000, 11, 427-438.

2. Epand R M and Vogel H J, Biochemica et Biophysica Acta, 1999, 1462, 11-28.

3. Michael Z, Curr Opin Immunol., 1992, 14, 3-7.

4. Michael Zasloff, Nature, 2002, 415, 389-395.

5. Jain M P, Koul S K, Dhar K L and Atal C K, Phytochem., 1980, 19, 1880-1882.

6. Santhosh B M and Narasimha P A, J Org Chem., 2001, 66, 9038-9040 and references cited therein

7. Suresh G P, Prakasha K C, Shiva Kumara K N, Kafpo W and Gowda D C, Int J Pept Res Ther., 2009, 15, 25-30.

8. (a) Witt A and Bergman J, Tetrahedron, 2000, 56, 7245-7253.

9. Lemriss S, Marquet B, Ginestet H, Lefeuvre L, Fassouane A and Boiron P, J Mycol Med., 2003, 13, 189-192.

10. Urry D W, Gowda D C, Hoban L D, Mekee A, Williams T, Olsen D B and Cox B A, In Biotechnological Polymers Medical, Pharmaceutical and Industrial Applications: Charles Gebelein G (Eds), Technomic Publiching Co Inc., 1993, 82-103

11. Krause E, Beyermann M, Dathe M, Rothemund S and Bienert M, Anal Chem., 1995, 67, 252-258.

12. Strom M B, Haug B E, Skar M L, Stensen W, Stilberg T and Svendsen J S, J Med Chem., 2003, 46, 1567-1570.

13. Hancock R E W, The Lancet Infect Dis., 2001, 1, 156-164.

14. Bechinger B, Biochim Biophys Acta., 1999, 1462, 157-183. 


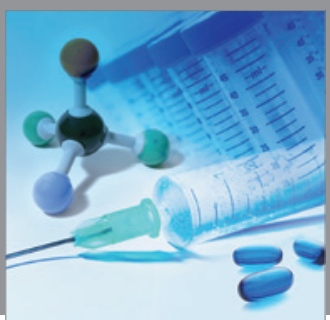

International Journal of

Medicinal Chemistry

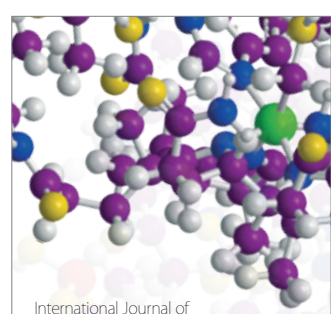

Carbohydrate Chemistry

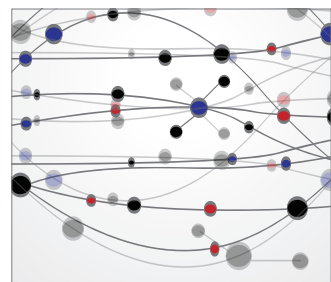

The Scientific World Journal
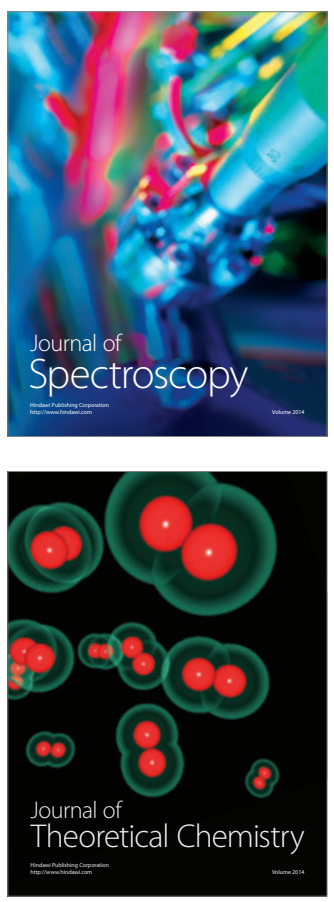
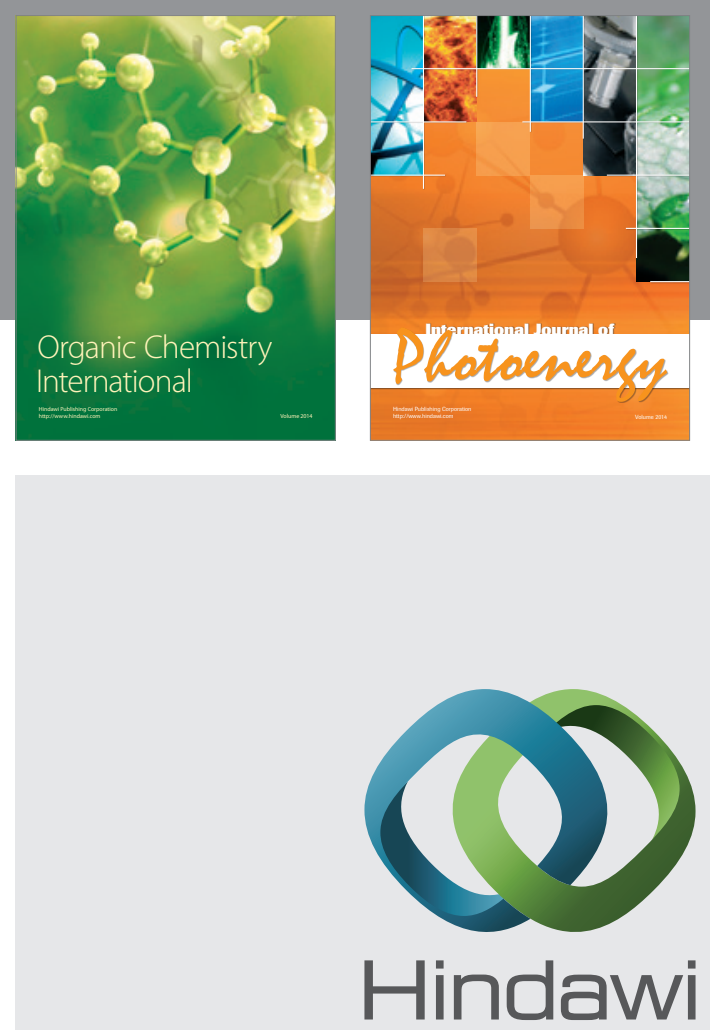

Submit your manuscripts at

http://www.hindawi.com
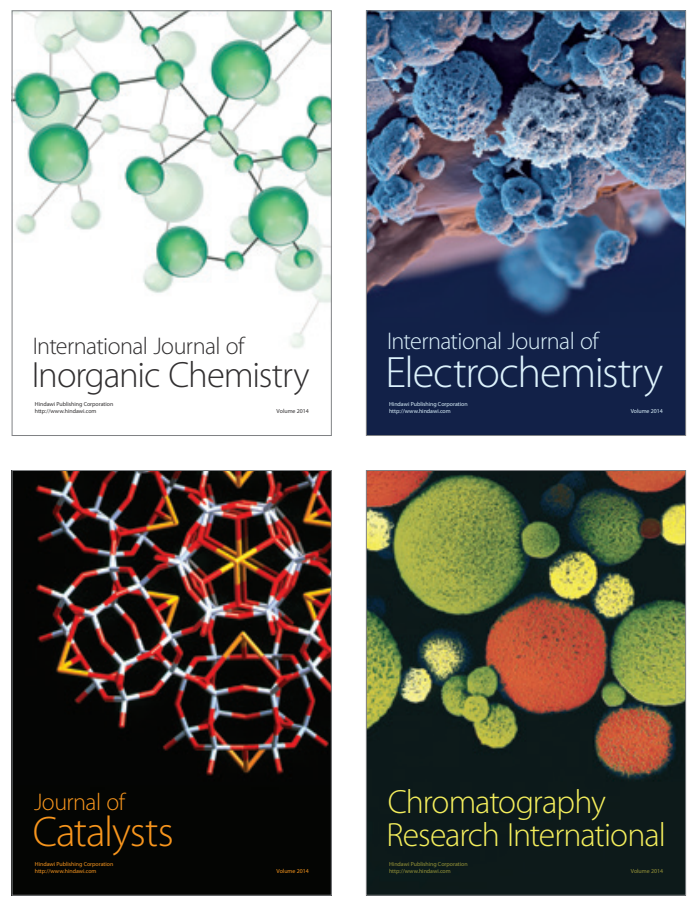
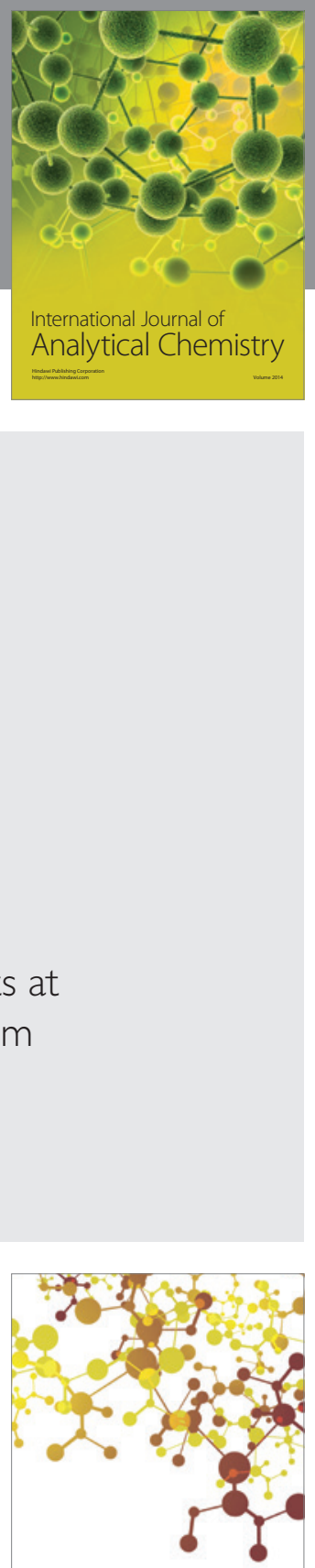

Journal of

Applied Chemistry
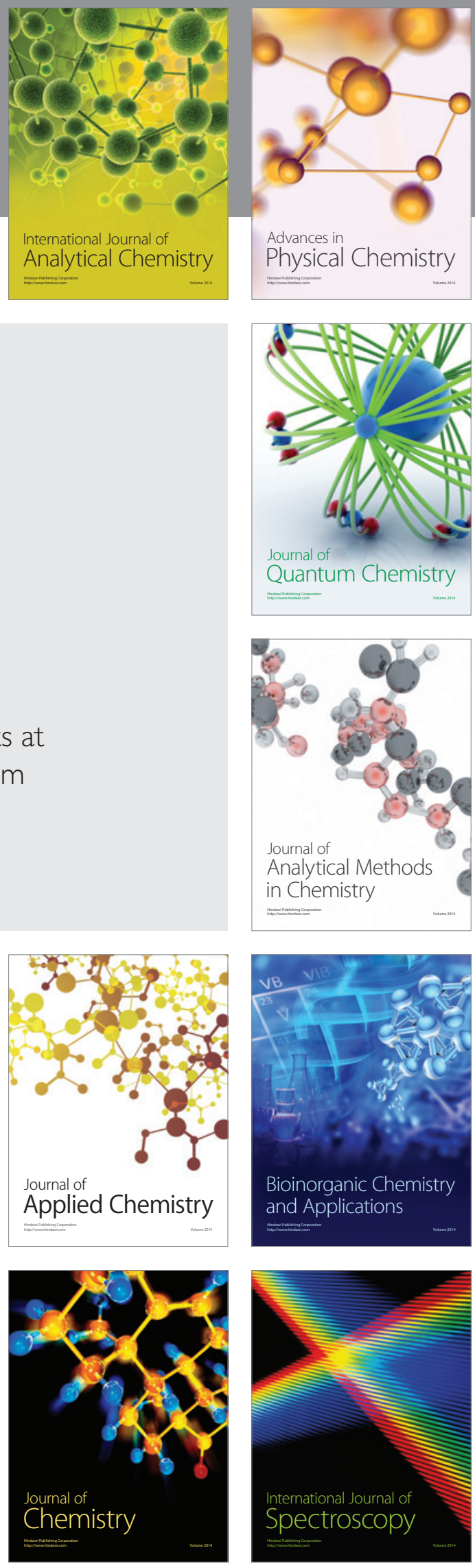